ks. Józef Stala*

Uniwersytet Papieski Jana Pawła II w Krakowie

\title{
ZMIANY POGLĄDÓW POLAKÓW \\ NA TEMAT UMIERANIA I ŚMIERCI \\ JAKO WYZWANIE PASTORALNE KOŚCIOŁA W POLSCE W XXI WIEKU
}

\section{Wprowadzenie psychologiczno-społeczne}

Lęk człowieka przed śmiercią nie jest zjawiskiem jednorodnym, bowiem w świetle badań wyróżniono trzy różne poziomy lęku przed własną śmiercią: świadomy, wyobrażeniowy, nieświadomy. Dodatkowo lęk przed śmiercią może być związany z obawą o własną śmierć, może dotyczyć śmierci innych ludzi, szczególnie znaczących emocjonalnie, ale może również odnosić się do zjawiska śmierci w znaczeniu ogólnym. U podłoża każdego z wymienionych lęków istnieją inne przyczyny. Stąd z psychologicznego i pedagogicznego punktu widzenia interesujące są badania empiryczne, które służą głębszemu poznawaniu zjawiska lęku przed

\footnotetext{
* KS. JÓZEF STALA - kapłan diecezji tarnowskiej, profesor nauk teologicznych (katechetyka), profesor zwyczajny Uniwersytetu Papieskiego Jana Pawła II w Krakowie (UPJPII), prorektor do spraw potencjału naukowego i współpracy międzynarodowej UPJPII. W latach 2010-2014 prodziekan do spraw nauki, rozwoju i współpracy zagranicznej oraz kierownik katedry nauk pedagogiczno-katechetycznych na Wydziale Teologicznym Sekcja w Tarnowie (WTST). Wykładowca katechetyki i kierownik pedagogizacji w tymże wydziale. Członek Europejskiej Ekipy Katechetycznej (EEC), Europejskiego Stowarzyszenia Teologii Katolickiej (ESTK), Stowarzyszenia Katechetyków Polskich, Polskiego Stowarzyszenia Familiologicznego, Polskiego Towarzystwa Teologicznego i Tarnowskiego Towarzystwa Naukowego. Redaktor naczelny międzynarodowego periodyku naukowego „The Person and the Challenges”. Ekspert (nauki teologiczne i nauki o rodzinie) Polskiej Komisji Akredytacyjnej (PKA). Rzeczoznawca Komisji Wychowania Katolickiego Konferencji Episkopatu Polski do spraw oceny programów nauczania religii i podręczników katechetycznych. Uczestnik i organizator konferencji, sympozjów i kongresów katechetycznych oraz edukacyjnych w Polsce i za granicą. Autor i redaktor wielu publikacji z zakresu katechetyki, pedagogiki i edukacji, a szczególnie katechezy rodzinnej, nauk o rodzinie, edukacji religijnej i wychowania. Współredaktor i współautor podręczników do nauczania religii.
} 
śmiercią i pomiarowi poziomu lęku przed śmiercią. Dużą pomocą w badaniach dotyczących lęku przed własną śmiercią są, prowadzone w latach siedemdziesiątych XX wieku, badania Hermana Feifela i Allana Branscomba ${ }^{1}$, którzy uwzględniali zarówno poziom lęku świadomego jak i nieświadomego.

W Polsce badania nad koncepcją lęku przed śmiercią zostały uwzględnione w pracach Antoniego Kępińskiego ${ }^{2}$ i Kazimierza Dąbrowskiego ${ }^{3}$. Ich zdaniem świadomość własnej śmierci skłania człowieka do poszukiwania rozwiązań pozwalających na przezwyciężanie obaw przed własnym ziemskim odejściem. Poszukiwanie sposobów opanowania lęku przed śmiercią sprzyja rozwojowi osobowości i wyrażania w pełni swojego człowieczeństwa. Zdaniem egzystencjalistów śmierć jest częścią ludzkiego doświadczenia, a ujawniający się lęk jest lękiem przed samym zjawiskiem śmierci, przed pustką i utratą sensu, a także przed winą i potępieniem. Natomiast zdaniem H. Feifela istnieją różne układy natężenia lęku przed śmiercią. Z jego badań wynika, iż najczęstsza sytuacja to zaprzeczanie przeżywania lęku na poziomie świadomym, przekonywanie innych, iż nie przeżywa się lęku przed śmiercią, ambiwalencja na poziomie fantazji oraz negacja śmierci. Dodatkowo H. Feifel wskazywał, że zewnętrzne wyrażanie braku lęku przed własną śmiercią jest związane ze zmiennością aprobaty społecznej. Prawdopodobnie $\mathrm{z}$ tego powodu w pomiarach lęku przed własną śmiercią mężczyźni uzyskują niższe wyniki niż kobiety ${ }^{4}$.

Natomiast zdaniem A. Kępińskiego można wskazać cztery podstawowe rodzaje lęku przed śmiercią: biologiczny, społeczny, moralny, dezintegracyjny. Z kolei zdaniem niektórych psychologów czynnikiem, który chroni przed lękiem przed śmiercią jest wysoka samoocena oraz znaczący udział w kulturze. Człowiek angażujący się w rozwój kultury wzmacnia swoją samoocenę, a dodatkowo odwraca uwagę od kwestii własnej śmiertelności. Wydaje się zatem, iż wysoka samoocena ugruntowana akceptacją społeczną przyczynia się do zmniejszenia lęku przed własną śmiercią. Dodatkowo wraz ze wzmocnieniem stanów chorobowych ludzie chorzy lub starsi coraz mocniej doświadczają nieuchronności śmierci i starają się do niej przygotować.

Zjawisko przygotowania do tzw. dobrej śmierci było mocno zakorzenione w polskiej tradycji. W środowisku rodziny „poszerzonej”, która obejmowała nie tylko rodziców i dzieci, ale również dziadków, kuzynów i innych krewnych, śmierć

\footnotetext{
1 Por. H. Feifel, A. Branscomb, Who's afraid of death, „Journal of Abnormal Psychology” 8 (1973) nr 3, s. $282-288$.

2 Por. A. Kępiński, Lęk, Warszawa 1977; A. Kępiński, Rytm życia, Kraków 1978; A. Kępiński, Schizofrenia, Kraków 1992.

3 Por. K. Dąbrowski, Zdrowie psychiczne i problem śmierci, „Zdrowie psychiczne” (1980) nr 4, s. 7-17.

4 Por. H. Feifel, Psychologia a śmierć, „Nowiny Psychologiczne” (1990) nr 5-6, s. 3-16.

5 Por. A. Kępiński, Lęk, Warszawa 1977.
} 
była postrzegana jako wydarzenie naturalne wkomponowane w rytm życia i funkcjonowania rodziny. Młodsze pokolenia miały szansę obserwować zmagania z bólem, cierpieniem i śmiercią, wspierać osoby starsze i cierpiące, i niejako do pewnego stopnia współuczestniczyć $\mathrm{w}$ ich procesie przygotowania do przejścia przez granicę śmierci. Dodatkowo w niektórych rejonach Polski, szczególnie w małych miejscowościach, funkcjonowała tradycja nie tylko rodzinnego, ale również społecznego z jednej strony przygotowania osoby do śmierci, a z drugiej pożegnania się z umierającą osobą. W społecznościach lokalnych ludzie umierający starali się skontaktować czy prosili o kontakt nie tylko członków rodziny, ale również sąsiadów i członków całej lokalnej społeczności. Dlatego w kulturze ludowej wyobcowanie ze swojego środowiska i umieranie poza domem rodzinnym było znakiem śmierci niegodnej człowieka. Umierając człowiek szlachetny winien być otoczony swoimi bliskimi, wzmocniony sakramentami przez kapłana i „rozliczony” ze sprawami ziemskimi. Natomiast w ujęciu psychologicznym i społecznym znaczące jest podjęcie badań empirycznych związanych z postawą w obliczu śmierci każdego człowieka i społeczeństw. Lęk przed własną śmiercią i obawa o śmierć zwłaszcza najbliższych skłaniają człowieka do podejmowania różnorodnych działań, do zmagania się z bólem, cierpieniem, chorobą, do przezwyciężania przeszkód zakorzenionych w biologii i budowania nadziei, wiary i empatii ${ }^{6}$.

\section{Stosunek Polaków do umierania i śmierci przed dwudziestu laty}

Centrum Badania Opinii Społecznej podejmowało kilkakrotnie badania dotyczące postaw Polaków wobec śmierci. Pierwsze badania dotyczące kwestii związanych ze śmiercią i umieraniem przeprowadzono $w$ wolnej Polsce $\mathrm{w}$ dniach 6-10 października 1994 roku na reprezentatywnej próbie dorosłych Polaków (1184 osoby) $)^{7}$. Jedna czwarta respondentów odpowiedziała, iż często myśli o śmierci i niepokoi ich myśl o niej. 38 proc. wskazało, iż od czasu do czasu podejmuje refleksję nad śmiercią, a natomiast 35proc. twierdziło, iż czyni to bardzo rzadko. W badaniach w 1994 roku wykazano, iż myśl o śmierci częściej pojawia się u osób starszych niż młodszych, chociaż co wydaje się interesujące, w grupie respondentów młodszych częstym myśleniem o śmierci wyróżniała się młodzież od 15-24

6 Por. J. Piotrowski, M. Żemojtel-Piotrowska, Skala lęku i fascynacją śmiercią, „Polskie Forum Psychologiczne" 14 (2009) nr 1, s. 90-109; Życie i śmierć. Wyzwania działalności charytatywnej, red. J. Stala, Tarnów 2012; Człowiek wobec bólu, cierpienia i śmierci, red. J. Stala, N. Bravená, Kraków 2013.

7 Zob. Centrum Badania Opinii Społecznej, Nasze postawy wobec umierania i śmierci. Komunikat z badań, Warszawa 1994 (BS/183/162/94), s. 1-17, http://www.cbos.pl/SPISKOM.POL/1994/K_162_94.PDF (21.08.2014). 
roku życia. Być może znaczące zmiany dokonujące się w życiu młodzieży (zmiana szkoły, kierunku studiów, podjęcie pracy) skłaniały ją do refleksji nad życiem i śmiercią. Znacznie częściej myślą o śmiercią kobiety niż mężczyźni, osoby religijne częściej niż niereligijne. Rzadziej myśl o śmierci deklarują osoby z wykształceniem zasadniczym zawodowym, osoby o najniższych dochodach, rolnicy i robotnicy. Najczęściej czynnikiem skłaniającym do zastanowienia nad zjawiskiem śmierci jest kontakt $\mathrm{z}$ człowiekiem umierającym lub oglądanie zwłok. Aż 94 proc. badanych wówczas Polaków odpowiedziało twierdząco, iż widziało ciało osoby zmarłej, przy czym połowa badanych była obecna przy śmierci innej osoby. Około jedna trzecia osób uczestniczyła bezpośrednio w przygotowaniu do pogrzebu innej osoby (myła, ubierała, ...). Grupa osób, które oglądały ciało osoby zmarłej wzrasta proporcjonalnie do wieku badanych. Statystycznie najczęściej przy osobie umierającej były osoby z wykształceniem podstawowym, mieszkańcy wsi, rolnicy i osoby zaangażowane religijnie. Widoczne jest też zróżnicowanie regionalne, bowiem najwyższy odsetek badanych potwierdzających doświadczenie obecności przy osobie umierającej pochodził z województw środkowozachodnich (dawne poznańskie i bydgoskie), południowozachodnich (opolskie i katowickie) oraz wschodnich. Na pytanie: „Myśli pan (pani) o śmierci ze strachem czy bez obaw?” 57 proc. badanych odpowiedziało, że śmierć nie budzi w nich strachu, a sam kontakt $\mathrm{z}$ człowiekiem umierającym lub pomoc $\mathrm{w}$ jego przygotowaniu do trumny przyczynia się do myślenia o śmierci, lecz bez obaw. Większy wpływ na myślenie o śmierci ze strachem przed nią ma obecność przy śmierci niż samo przygotowanie osoby zmarłej do pogrzebu. 34 proc. respondentów wskazało, iż myśląc o śmierci przeżywa lęk przed nią. Zgodnie z przeprowadzonymi badaniami myślenie o śmierci bez lęku ma związek $\mathrm{z}$ wiekiem badanych oraz ich zaangażowaniem religijnym zwłaszcza regularnym udziałem w praktykach religijnych. Bez lęku przed śmiercią myślą o niej częściej mężczyźni niż kobiety, mieszkańcy wschodnich województw oraz wsi i małych miejscowości, a także rolnicy, renciści i emeryci ${ }^{8}$. Respondentów poproszono również o odniesienie się do poniższych twierdzeń: „Śmierć jest zbyt okropna by ją oglądać i mówić o niej”; „Bardzo obawiam się śmierci i umierania”; „Śmierć jest czymś naturalnym i trzeba się z nią pogodzić". Aż 86 proc. respondentów uznało, że śmierć należy traktować jak coś naturalnego, wpisanego w życie człowieka. Natomiast 6 proc. badanych uznało, że śmierć jest zbyt straszna, by ja oglądać, dyskutować o niej, zastanawiać się nad nią. Stosunek do śmierci uwidocznił się również w wypowiedziach dotyczących przygotowania do niej. 47 proc. badanych uznało, że lepiej nie myśleć o śmierci

\footnotetext{
8 Por. Centrum Badania Opinii Społecznej, Nasze postawy wobec umierania i śmierci. Komunikat $z$ badań, Warszawa 1994 (BS/183/162/94), s. 5, http://www.cbos.pl/SPISKOM.POL/1994/K_162_94.PDF (21.08.2014).
} 
i nie przygotowywać się do niej podczas, gdy taka sama statystycznie grupa respondentów (47 proc.) przyznała, iż śmierć wymaga odpowiedniego przygotowania. Dla wielu badanych ważne są kwestie majątkowe, określenie miejsca i sposobu pochówku, czy przygotowania odpowiedniego nagrobka. Odsetek badanych, którzy podkreślali potrzebę czy konieczność przygotowania się do śmierci wzrasta $\mathrm{z}$ wiekiem, religijnością i wysokością dochodów. Zebrano również interesujące dane dotyczące świadomości umierania. 26 proc. respondentów uważało, iż lepiej gdy człowiek umiera świadomie i w tej grupie jest więcej zwolenników przygotowań do śmierci ( 65 proc.). Natomiast 66 proc. badanych Polaków uznało, iż lepiej umierać nieświadomie, np. we śnie lub niespodziewanie. Ten wynik badań jest dość zaskakujący i odmienny od XIX wiecznego wzoru śmierci świadomej, po dokonaniu rachunku z własnego życia. Wydaje się również pozostawać w zderzeniu ze wzorem chrześcijańskim, według którego wierzący proszą o zachowanie ich od nagłej i niespodziewanej śmierci9.

Większość badanych Polaków w 1994 roku wierzy, iż śmierć kończy tylko ziemskie życie (natomiast istnieje jeszcze „coś” po śmierci). Trzeba jednak zauważyć, iż odsetek badanych przekonanych o życiu pozagrobowym jest znacznie mniejszy niż odsetek osób deklarujących się jako osoby wierzące. 57 proc. badanych osób uznało, że po śmierci jest dalsze życie, 24 proc. nie umiało wypowiedzieć się w tej kwestii, natomiast 19 proc. podało, że śmierć kończy ich istnienie. W życie po śmierci częściej wierzą kobiety i mieszkańcy wsi oraz małych miast. Grupę respondentów, która odpowiedziała pozytywnie opowiadając się za życiem po śmierci, poproszono również o próbę określenia tej formy egzystencji. Warto zaznaczyć, że otrzymane odpowiedzi były raczej skrótowe i ogólnikowe. Wszystkie wypowiedzi można podzielić na trzy grupy. Najczęściej respondenci (55 proc.) wskazywali na istnienie duszy, ducha i życia dusz oraz odwoływali się do nowego życia poza ciałem albo po prostu wskazywali na życie pozagrobowe bez dodatkowych dopowiedzi. Druga grupa respondentów (36 proc.) udzieliła odpowiedzi wskazując na religię, Kościół, wiarę. Bardzo często podawano: „zgodnie z wiarą” lub „zgodnie z tym, co nakazuje Kościół”. Natomiast trzecia grupa (11 proc. badanych) wskazała na jakieś życie lub istnienie nie podając przy tym żadnych religijnych uzasadnień ${ }^{10}$.

Interesujące odpowiedzi uzyskano $\mathrm{w} 1994$ roku stawiając pytanie o godną śmierć. Zgodnie z uzyskanymi danymi 68 proc. badanych Polaków uważa, iż jest

\footnotetext{
9 Por. Centrum Badania Opinii Społecznej, Nasze postawy wobec umierania i śmierci. Komunikat z badań, Warszawa 1994 (BS/183/162/94), s. 6-7, http://www.cbos.pl/SPISKOM.POL/1994/K_162_94.PDF (21.08.2014).

${ }^{10}$ Por. Centrum Badania Opinii Społecznej, Nasze postawy wobec umierania i śmierci. Komunikat z badań, Warszawa 1994 (BS/183/162/94), s. 8-11, http://www.cbos.pl/SPISKOM.POL/1994/K_162_94.PDF (21.08.2014).
} 
lepiej, gdy człowiek umiera w domu, a tylko 18 proc. podaje, iż lepiej jeśli umiera w szpitalu czy innym ośrodku opieki medycznej. Śmierć w szpitalu jest zdecydowanie postrzegana jako umieranie w osamotnieniu i w złych warunkach, co prawdopodobnie w dużym stopniu odzwierciedla przekonanie o złym stanie i organizacji instytucji medycznych w naszym kraju. Co ciekawie częściej wskazują dom nie tylko ludzie starsi i bardziej religijni, ale także młodzi respondenci, inteligencja i osoby niewierzące, co może wskazywać, iż obok tradycyjnego wzorca umierania w otoczeniu najbliższych kształtuje się nowy wzorzec związany z krytycznym nastawieniem do śmierci w instytucji medycznej i unikania takiej sytuacji. Badanym Polakom postawiono również pytanie o oczekiwaną formę pochówku. 55 proc. respondentów uznało, że należy chować ciało w trumnie. Jednak już 37 proc. opowiedziało się za możliwością kremacji ciała. Respondentom zadano również pytanie dotyczące kontaktu dzieci ze śmierci. Odpowiedzi na nie były bardzo podzielone i zróżnicowane. Grupa osób opowiadających się za izolowaniem dzieci od spraw związanych ze śmiercią i dopuszczających dzieci do kontaktu ze śmiercią okazały się niemal tak samo liczne. 45proc. uznało, iż dzieci nie powinny stykać się ze śmiercią, a 43 proc. iż kontakt ze śmiercią jest potrzebny dla ich rozwoju ${ }^{11}$.

Tabela $1^{12}$

\begin{tabular}{|l|c|c|c|c|c|}
\hline \multirow{2}{*}{$\begin{array}{c}\text { Czy, Pana(i) zdaniem, dzieci powinny } \\
\text { czy też nie powinny: }\end{array}$} & \multicolumn{5}{c|}{ Wskazania respondentów w procentach } \\
\cline { 2 - 6 } & tak & $\begin{array}{c}\text { raczej } \\
\text { tak }\end{array}$ & $\begin{array}{c}\text { raczej } \\
\text { nie }\end{array}$ & Nie & $\begin{array}{c}\text { trudno } \\
\text { powiedzieć }\end{array}$ \\
\hline - uczestniczyć w pogrzebach osób bliskich i znajomych & 58 & 34 & 2 & 3 & 2 \\
\hline $\begin{array}{l}\text { - nosić na co dzién przez jakiś czas żałobę po śmierci } \\
\text { kogoś z rodziny }\end{array}$ & 39 & 26 & 19 & 13 & 3 \\
\hline - widzieć zwłoki osób zmarłych & 18 & 37 & 22 & 17 & 5 \\
\hline $\begin{array}{l}\text { - widzieć martwe zwierzęta, które chowano w domu } \\
\text { i z którymi się bawiły, np. kota, psa, chomika, papuż- } \\
\text { kę, kanarka itp. - jeśli któreś z nich padnie (umrze) }\end{array}$ & 15 & 24 & 28 & 25 & 7 \\
\hline - być przy czyjejś śmierci, np. osób bliskich & 15 & 23 & 30 & 27 & 7 \\
\hline - pomagać w pielęgnacji osób umierających & 15 & 18 & 32 & 33 & 3 \\
\hline
\end{tabular}

Zdecydowana większość badanych (92 proc.) popiera udział dzieci w pogrzebach bliskich im osób. Podobnie wysoki współczynnik akceptacji zyskuje noszenie

\footnotetext{
${ }^{11}$ Por. Centrum Badania Opinii Społecznej, Nasze postawy wobec umierania i śmierci. Komunikat z badań, Warszawa 1994 (BS/183/162/94), s. 12-13, http://www.cbos.pl/SPISKOM.POL/1994/K_162_94.PDF (21.08.2014).

${ }^{12}$ Por. Centrum Badania Opinii Społecznej, Nasze postawy wobec umierania i śmierci. Komunikat z badań, Warszawa 1994 (BS/183/162/94), s. 14, http://www.cbos.pl/SPISKOM.POL/1994/K_162_94.PDF (21.08.2014).
} 
przez dzieci oznak żałoby. Znacznie mniej ankietowanych Polaków uważa, iż dzieci powinny oglądać osoby zmarłe ( 55 proc.), a 39 proc. respondentów popiera kontakt dzieci z martwymi zwierzętami, którymi wcześniej opiekowały się. 38 proc. opowiada się pozytywnie za obecnością dziecka przy śmierci np. osoby bliskiej, natomiast 33 proc. opowiada się pozytywnie za pomocą dzieci w pielęgnacji osób umierających. Można wyraźnie dostrzec związek między odczuwaniem lęku przed śmiercią a postawami respondentów wobec kontaktu dzieci ze śmiercią. Respondenci, którzy obawiają się śmierci i myślą o niej z lękiem są częściej przekonani, że dzieci należy izolować od śmierci. Najmniej zróżnicowane są zdania dotyczące udziału dzieci w pogrzebach i noszenie przez nie znaków związanych z żałobą ${ }^{13}$.

Zgodnie $\mathrm{z}$ danymi uzyskanymi podczas przeprowadzonych badań w 1994 roku na postawy Polaków wobec umierania i śmierci duży wpływ ma obyczajowość, religijność oraz wiek. Środowiska wiejskie, silniej związane z tradycyjną obyczajowością, charakteryzują się bardziej naturalnym odniesieniem do śmierci. Kontakt z nią jest częstszy a myśl o niej budzi mniej lęku. Dodatkowo w tych środowiskach silniejsza jest akceptacja obecności dzieci przy śmierci, ich kontaktu z ciałem zmarłego, czy symboliczne wyrażanie przez nie żałoby. Ludzie starsi, którzy częściej pozostają w kontakcie ze śmiercią, traktują ja bardziej naturalnie i czynią do niej odpowiednie przygotowanie. Natomiast osoby wykształcone, szczególnie z wyższym wykształceniem, a zwłaszcza w dużych miastach, mają mniej tradycyjny a bardziej emocjonalny stosunek do śmierci, częściej negują obecność dzieci przy śmierci, ale w niektórych sprawach wydają się bardziej otwarci, np. przygotowując plany na wypadek śmierci ${ }^{14}$.

\section{Stosunek Polaków do umierania i śmierci w XXI wieku}

Badania nad zagadnieniem śmierci i umierania zostały ponowione przez Centrum Badania Opinii Społecznej (CBOS) w 2001 ${ }^{15}, 2005^{16}$ oraz $2012^{17}$ roku. Wydaje się, iż chociaż nadal trzy czwarte Polaków wskazuje, iż myśli o śmierci, to jednak

\footnotetext{
${ }^{13}$ Por. Centrum Badania Opinii Społecznej, Nasze postawy wobec umierania i śmierci. Komunikat z badań, Warszawa 1994 (BS/183/162/94), s. 14, http://www.cbos.pl/SPISKOM.POL/1994/K_162_94.PDF (21.08.2014).

${ }_{14}$ Por. Centrum Badania Opinii Społecznej, Nasze postawy wobec umierania i śmierci. Komunikat $z$ badań, Warszawa 1994 (BS/183/162/94), s. 17, http://www.cbos.pl/SPISKOM.POL/1994/K_162_94.PDF (21.08.2014).

${ }^{15}$ Zob. Centrum Badania Opinii Społecznej, O umieraniu i śmierci. Komunikat z badań, Warszawa 2001 (BS/146/2001), s. 1-17, http://www.cbos.pl/SPISKOM.POL/2001/K_146_01.PDF (21.08.2014).

${ }^{16}$ Zob. Centrum Badania Opinii Społecznej, Stosunek Polaków do śmierci. Komunikat z badań, Warszawa 2005 (BS/98/2005), s. 1-12, http://www.cbos.pl/SPISKOM.POL/2005/K_098_05.PDF (21.08.2014).

17 Zob. Centrum Badania Opinii Społecznej, W obliczu śmierci. Komunikat z badań, Warszawa 2012 (BS/165/2012), s. 1-5, http://www.cbos.pl/SPISKOM.POL/2012/K_165_12.PDF (21.08.2014).
} 
coraz więcej rodaków twierdzi, że nie zastanawia się nad tymi kwestiami. W ciągu ostatnich dziesięciu lat refleksyjność nad śmiercią zmniejszyła się o 9 punktów proc. - do 20 proc., a o 6 punktów proc. przybyło tych, którzy nigdy nie zastanawiają się nad zjawiskiem śmierci ${ }^{18}$. Trudno zestawiać dane uzyskane po 2000 roku z danymi uzyskanymi w 1994 roku, ponieważ inaczej formułowano pytania i podawano inne możliwości, stosując inną skalę odpowiedzi. Jednak można ogólnie stwierdzić, iż w 1994 roku więcej osób, przynajmniej deklaratywnie stwierdziło, iż myśli o śmierci i znacznie mniej osób podawało, iż czyni to bardzo rzadko lub prawie nigdy (w 1994 roku 35 proc.) ${ }^{19}$.

Tabela $2^{20}$

\begin{tabular}{|c|c|c|c|c|c|c|}
\hline \multirow{3}{*}{ Czy Pan(i) myśli o śmierci: } & \multicolumn{6}{|c|}{ Odpowiedzi respondentów według terminów badań } \\
\hline & \multicolumn{2}{|c|}{2001} & \multicolumn{2}{|c|}{2005} & \multicolumn{2}{|c|}{2012} \\
\hline & \multicolumn{6}{|c|}{ w procentach } \\
\hline - bardzo często & 10 & \multirow{2}{*}{29} & 8 & \multirow{2}{*}{26} & 4 & \multirow{2}{*}{20} \\
\hline - dość często & 19 & & 18 & & 16 & \\
\hline - dość rzadko & 23 & \multirow[b]{2}{*}{49} & 21 & \multirow[b]{2}{*}{45} & 26 & \multirow[b]{2}{*}{52} \\
\hline - bardzo rzadko & 26 & & 24 & & 26 & \\
\hline - nigdy & \multicolumn{2}{|c|}{22} & \multicolumn{2}{|c|}{29} & \multicolumn{2}{|c|}{28} \\
\hline
\end{tabular}

Można również zaobserwować zmiany dotyczące przygotowania się do śmierci. W opinii Polaków z 1994 roku 47 proc. uważało, iż lepiej przygotować się do śmierci. Natomiast w 2012 roku tylko 20 proc. twierdziło, iż chciałoby mieć czas na przygotowanie się do śmierci. Znacznie więcej, bo aż 71 proc. w 2012 roku uznało, iż chciałby umrzeć niespodziewanie, podczas gdy w 1994 roku 47 proc. uważało, że nie należy myśleć o śmierci i nie należy czynić żadnych planów. W 2012 roku życzenie nagłej śmierci częściej wyrażają badani z wykształceniem zasadniczym zawodowym, gorzej sytuowani finansowo i mniej praktykujący. Jednak za „szybką" śmiercią opowiadają się w dużym stopniu badani ze wszystkich grup społecznodemograficznych. Respondenci, którzy wskazują na potrzebę przygotowania się do śmierci wymieniają elementy znaczące w procesie przygotowania się do śmierci. 81 proc. chciałby się pożegnać z najbliższymi, 71 proc. w tej grupie wskazuje

${ }^{18}$ Por. Centrum Badania Opinii Społecznej, W obliczu śmierci. Komunikat z badań, Warszawa 2012 (BS/165/2012), s. 2, http://www.cbos.pl/SPISKOM.POL/2012/K_165_12.PDF (21.08.2014).

${ }^{19}$ Por. Centrum Badania Opinii Społecznej, Nasze postawy wobec umierania i śmierci. Komunikat $z$ badań, Warszawa 1994 (BS/183/162/94), s. 2, http://www.cbos.pl/SPISKOM.POL/1994/K_162_94.PDF (21.08.2014).

${ }^{20}$ Por. Centrum Badania Opinii Społecznej, W obliczu śmierci. Komunikat z badań, Warszawa 2012 (BS/165/2012), s. 2, http://www.cbos.pl/SPISKOM.POL/2012/K_165_12.PDF (21.08.2014). 
na potrzebę przyjęcia sakramentów. Natomiast 62 proc. pragnie uporządkować sprawy finansowo-majątkowe. Co ciekawe tylko 42 proc. wskazuje na potrzebę naprawienia relacji międzyludzkich, pogodzenie się z innymi. Dla 24 proc. respondentów ważne jest zapewnienie sobie miejsca na cmentarzu, natomiast 10 proc. chciałoby przed śmiercią spełnić swoje marzenie lub wyjechać w podróż ${ }^{21}$.

Ilustracja 1. Odpowiedzi respondentów, którzy chcieliby mieć czas, aby przygotować się do śmierci $(n=192)$.

\begin{tabular}{|c|c|}
\hline & CBOS \\
\hline \multicolumn{2}{|c|}{ W jaki sposób chciał(a)by Pan(i) przygotować się do śmierci? } \\
\hline Pożegnać się z bliskim, rodziną, przyjaciółmi & $81 \%$ \\
\hline Wyspowiadać się, przyjąć sakramenty & $71 \%$ \\
\hline $\begin{array}{l}\text { Uporządkować sprawy majątkowe, sporządzić } \\
\text { testament }\end{array}$ & $62 \%$ \\
\hline $\begin{array}{l}\text { Pogodzić się z osobą(ami), z którą(ymi) jestem } \\
\text { w konflikcie }\end{array}$ & $42 \%$ \\
\hline Zapewnić sobie miejsce na cmentarzu & $24 \%$ \\
\hline Zrobić jeszcze coś innego & $10 \%$ \\
\hline Trudno powiedzieć & $8 \%$ \\
\hline
\end{tabular}

Procenty nie sumują się do 100, ponieważ respondenci mogli wskazać wszystkie ważne dla nich sprawy.

Respondenci mają różne wyobrażenia związane z umieraniem. 59 proc. chciałby umrzeć we śnie, natomiast dla 50 proc. ważne, aby zakończenie życia nie było związane z długim cierpieniem. 32 proc. pragnie mieć możliwość pożegnania się z rodziną i przyjaciółmi, 29 proc. wskazuje na pragnienie przyjęcia sakramentów (spowiedź, Eucharystia i namaszczenie chorych). W wyobrażeniu 25 proc. badanych bardzo ważne jest umieranie we własnym domu, zaś 15 proc. badanych uważa za najistotniejszą kwestię obecności bliskiej osoby. 7 proc. chce umierać

\footnotetext{
${ }^{21}$ Por. Centrum Badania Opinii Społecznej, W obliczu śmierci. Komunikat z badań, Warszawa 2012 (BS/165/2012), s. 2-3, http://www.cbos.pl/SPISKOM.POL/2012/K_165_12.PDF (21.08.2014).
} 
zachowując świadomość, a 7 proc. wskazuje na elementy estetyczne - pragnie aby śmierć nie zniekształciła ich ciała. Dane zostały przedstawione na poniższym rysunku ${ }^{22}$ :

Ilustracja 2. Ludzie różnie wyobrażają sobie swoją śmierć. Jak Pan(i) sobie ją wyobraża? Jak chciał(a)by Pan(i) umrzeć? Co byłoby dla Pana(i) najważniejsze?

\begin{tabular}{|c|c|}
\hline & CBOS \\
\hline Umrzeć we śnie & $59 \%$ \\
\hline Umrzeć nie cierpiąc długo & $50 \%$ \\
\hline $\begin{array}{l}\text { Pożegnać się przed śmiercią z bliskimi: rodzi- } \\
\text { ną i przyjaciółmi }\end{array}$ & $32 \%$ \\
\hline $\begin{array}{l}\text { Przed śmiercią wyspowiadać się, przyjąć } \\
\text { sakramenty }\end{array}$ & $29 \%$ \\
\hline Umrzeć we własnym domu & $25 \%$ \\
\hline Umierać z osobą bliską u boku & $15 \%$ \\
\hline Umierać zachowując świadomość & $7 \%$ \\
\hline $\begin{array}{l}\text { Umrzeć w taki sposób, by moje ciało nie było } \\
\text { zniekształcone }\end{array}$ & $7 \%$ \\
\hline Trudno powiedzieć, nie myślałe(a)m o tym & $6 \%$ \\
\hline
\end{tabular}

Procenty nie sumują się do 100, ponieważ respondenci mogli wskazać trzy najważniejsze dla nich sprawy.

Respondenci lepiej wykształceni i majętni podkreślają częściej społeczny aspekt śmierci i wskazują na pragnienie pożegnania się z bliskimi lub umierania u boku ukochanej osoby. Natomiast gorzej wykształceni i mniej majętni wolą pozostać i umrzeć w swoim domu, zaś osoby głęboko wierzące i zaangażowane religijne podkreślają wartość sakramentów. Na pytanie „gdzie chciałby (chciałaby) Pan (Pani) umrzeć?" w 2012 roku 66 proc. respondentów określiło jako miejsce swojej śmierci własny dom. Podczas, gdy w 1994 roku uczyniło tak 68 proc. Nadto w 2012 roku 8 proc. wolało umrzeć w szpitalu, podczas gdy w 1994 roku wskazało na szpital 18 proc., natomiast w 2012 roku pojawiły się opinie, iż lepiej umrzeć

\footnotetext{
${ }^{22}$ Por. Centrum Badania Opinii Społecznej, W obliczu śmierci. Komunikat z badań, Warszawa 2012 (BS/165/2012), s. 4, http://www.cbos.pl/SPISKOM.POL/2012/K_165_12.PDF (21.08.2014).
} 
w innym miejscu, np. na wyjeździe zagranicznym, na łonie natury, w pracy. Podczas gdy w 1994 roku 14 proc. nie miało zdania na ten temat, to w 2012 roku 22 proc. ankietowanych nie umie wskazać, gdzie chciałby umrzeć ${ }^{23}$.

Tabela $3^{24}$

\begin{tabular}{|l|c|c|c|}
\hline \multirow{2}{*}{$\begin{array}{c}\text { Jak Pan(i) myśli, czy śmierć kończy nasze ży- } \\
\text { cie, czy też jest jeszcze coś po śmierci? }\end{array}$} & \multicolumn{3}{|c|}{ Wskazania respondentów według terminów badań } \\
\cline { 2 - 4 } & $\begin{array}{c}\text { październik } \\
\mathbf{1 9 9 4}\end{array}$ & $\begin{array}{c}\text { październik } \\
\mathbf{2 0 0 1}\end{array}$ & \multicolumn{2}{|c|}{ maj 2005 } \\
\cline { 2 - 4 } & \multicolumn{3}{|c|}{ wrocentach } \\
\hline Nic nie ma po śmierci & 19 & 14 & 13 \\
\hline Jest jeszcze coś po śmierci & 57 & 69 & 65 \\
\hline Trudno powiedzieć & 24 & 17 & 22 \\
\hline
\end{tabular}

W 2012 roku nie pytano respondentów o ich przekonania o życiu po śmierci, natomiast to pytanie pojawiło się w badaniach z 2005 roku. Wówczas 65 proc. badanych wyraziło przekonanie, iż śmierć nie jest ostatecznym zakończeniem. Podczas gdy podobną deklarację w 1994 roku złożyło 57 proc., a w 2001 roku 69 proc. Zatem odsetek osób wierzących w życie po śmierci zwiększył się w stosunku do 1994 roku o 8 punktów proc., nadal zmalał w stosunku do 2001 roku o 4 punkty proc. Wyraźnie zmalał odsetek osób deklarujących przekonanie, iż nie ma nic po śmierci (z 19 proc. w 1994 roku, do 14 proc. w 2001 roku i do 13 proc. w 2005 roku). W 2005 roku zwiększyła się o 5 punktów proc. grupa osób w stosunku do 2001 roku tych respondentów, którzy nie mają zdania w kwestii eschatologicznej. Ich odsetek wynosi obecnie 22 proc., co jest porównywalne z 1994 rokiem (24 proc.). Respondentów, którzy uznają, iż śmierć nie stanowi końca ludzkiego życia, poproszono o wyjaśnienie w pytaniu otwartym, co ich zdaniem będzie po śmierci. 78 proc. badanych z tej grupy mówiło o innym życiu, chociaż podawało jego różne określenia. 39 proc. badanych wskazywało na życie pozagrobowe, 23 proc. odwoływało się do życia wiecznego lub życia z Bogiem, natomiast co dziesiąty badany opisywał lepsze, bezbolesne, spokojne, bezkonfliktowe życie. Jedynie 6 proc.

\footnotetext{
${ }^{23}$ Por. Centrum Badania Opinii Społecznej, W obliczu śmierci. Komunikat z badań, Warszawa 2012 (BS/165/2012), s. 5, http://www.cbos.pl/SPISKOM.POL/2012/K_165_12.PDF (21.08.2014).

${ }^{24}$ Por. Centrum Badania Opinii Społecznej, Stosunek Polaków do śmierci. Komunikat z badań, Warszawa 2005 (BS/98/2005), s. 5, http://www.cbos.pl/SPISKOM.POL/2005/K_098_05.PDF (21.08.2014).
} 
respondentów określiło życie po śmierci jako życie duchowe lub życie w duchu. Szczegółowe odpowiedzi widzimy poniżej ${ }^{25}$ :

\begin{tabular}{|c|c|}
\hline & CBOS \\
\hline C o, Pana(i) zdaniem jest p o ś m i e r c i ? & $\mathrm{N}=68 \mathrm{o}$ \\
\hline Drugie życie, nowe życie, dalsze życie, życie po śmierci, życie pozagrobowe & $39 \%$ \\
\hline Życie wieczne, wieczność, życie wiekuiste, szczęście wieczne, życie z Bogiem & $23 \%$ \\
\hline Lepsze życie, szczęśliwe życie, lepszy świat, życie beztroskie, bezbolesne & $10 \%$ \\
\hline Niebo, raj (bez wzmianki o czyśćcu i piekle) & $8 \%$ \\
\hline Życie duchowe, życie dusz, życie w duchu, świat dusz, duch & $6 \%$ \\
\hline Niebo lub piekło (bez wzmianki o czyśćcu) & $5 \%$ \\
\hline Niebo, czyściec, piekło (wszystkie łącznie) & $2 \%$ \\
\hline Zmartwychwstanie & $2 \%$ \\
\hline Sąd Ostateczny, Sąd Boży, nagroda lub kara, szczęście wieczne lub potępienie & $2 \%$ \\
\hline Inna rzeczywistość, jakaś forma bytu, energii, siły duchowej, stanu świadomości & $2 \%$ \\
\hline Spotkanie z rodziną, bliskimi, połączenie z bliskimi, którzy wcześniej umarli & $2 \%$ \\
\hline Wędrówka dusz, życie dusz na ziemi, pielgrzymowanie dusz & $1 \%$ \\
\hline Reinkarnacja, inne wcielenie, następne życie na Ziemi & $1 \%$ \\
\hline Czyściec, pokuta & $1 \%$ \\
\hline Jest jeszcze coś, ale nie wiadomo co, trudno powiedzieć, nie wiem & $13 \%$ \\
\hline
\end{tabular}

Odsetki nie sumują się do 10o, ponieważ niektórzy respondenci używali więcej niż jednego określenia na to, co ich zdaniem jest po śmierci.

Warto dodać, iż w co piątej wypowiedzi pojawiły się terminy teologiczne (zmartwychwstanie, niebo, piekło, czyściec), z czego większość (8 proc.) wypowiedzi dotyczyła nieba, natomiast 5 proc. wskazywała na niebo lub piekło. Znacznie

\footnotetext{
${ }^{25}$ Por. Centrum Badania Opinii Społecznej, Stosunek Polaków do śmierci. Komunikat z badań, Warszawa 2005 (BS/98/2005), s. 6, http://www.cbos.pl/SPISKOM.POL/2005/K_098_05.PDF (21.08.2014).
} 
rzadziej życie po śmierci ujmowali respondenci w określenia innego wymiaru, energii ( 2 proc.) lub spotkania ze zmarłymi członkami rodziny ( 2 proc.), a tylko 1 proc. badanych wskazał na reinkarnację lub wędrówkę dusz. W zestawieniu z wynikami badań z 1994 roku w 2005 roku respondenci częściej opisywali życie po śmierci jako znacznie lepsze jakościowo - nastąpił wzrost o 5 punktów proc. Częściej ujawniły się również wypowiedzi wskazujące na kategorie religijne - wzrost o 4 punkty proc., co może być związane z głębokim doświadczeniem śmierci papieża Jana Pawła II. Pomimo, iż znaczny procent społeczeństwa w Polsce stanowią chrześcijanie (przede wszystkim katolicy), to jednak stosunek do śmierci i spraw eschatologicznych nie potwierdza w pełni przekonania wierzących o istnieniu innej rzeczywistości po śmierci. Prawdopodobnie również śmierć ojca świętego Jana Pawła II pobudziła niektórych Polaków do pogłębionej refleksji nad zjawiskiem umierania, śmierci i wszystkimi zagadnieniami z nią związanymi. Natomiast w 2012 roku wzrósł odsetek osób nie podejmujących pogłębionej refleksji nad śmiercią ${ }^{26}$.

\section{Refleksje teologiczno-pastoralne}

W Katechizmie Kościoła Katolickiego przypomniano, iż choroba, cierpienie i śmierć należą do fundamentalnych problemów ludzkiego życia. W sytuacji poważnej choroby człowiek doświadcza swojej niemocy, słabości, bezradności i ograniczeń. Każda poważna choroba niesie też ze sobą ryzyko śmierci (Por. KKK 1500). Wobec choroby i śmierci człowiek może przyjąć zróżnicowane postawy, może zamknąć się w sobie a niekiedy nawet buntować wobec Boga, ale może także przyjąć cierpienie i chorobę jako znaczące elementy na drodze ku dojrzałości. Cierpienie, choroba, świadomość zbliżającej się śmierci mogą także pobudzać człowieka do poszukiwania sensu życia, stawiania fundamentalnych pytań, poszukiwania na nowo podstawowych wartości, mogą skłonić go do szukania Boga i powrotu do Niego (Por. KKK 1501). W ten sposób choroba może stać się początkiem nawrócenia. W ujęciu chrześcijańskim podkreśla się fakt, iż Jezus mając moc uzdrawiania i lecząc choroby człowieka traktował go całościowo, integralnie, nie skupiał się wyłącznie na fizycznym, biologicznym wymiarze choroby, ale oczekiwał od chorych wiary i dokonywał uzdrowienia całego człowieka, duszy i ciała (Por. KKK 1503-1504). Jednocześnie Jezus sam nie unikał trudnych sytuacji bólu, cierpienia, lecz poprzez swoją mękę i śmierć na krzyżu nadał cierpieniu nowe znaczenie

\footnotetext{
${ }^{26}$ Por. Centrum Badania Opinii Społecznej, W obliczu śmierci. Komunikat z badań, Warszawa 2012 (BS/165/2012), s. 8, http://www.cbos.pl/SPISKOM.POL/2012/K_165_12.PDF (21.08.2014).
} 
- każdy wierzący w Niego może się do Niego upodabniać i ofiarować swoje cierpienie i chorobę, jednoczyć się z Jego zbawczą męką (Por. KKK 1505). W tradycji liturgicznej Kościoła od czasów starożytnych stosowano namaszczenie chorych poświęconym olejem. Kolejne wieki spowodowały silniejsze powiązanie namaszczenia chorych z namaszczeniem udzielanym ludziom umierającym, stąd ten sakrament zyskał również nazwę „ostatniego namaszczenia”. Jednak Kościół w liturgii nie przestawał prosić Boga o zdrowie chorego, przy czym ważniejsze niż jego zdrowie fizyczne jest jego zbawienie (Por. KKK 1512). Dlatego jeżeli człowiek chory, który otrzymał namaszczenie chorych odzyskał zdrowie, to w sytuacji następnej poważnej choroby może ponownie przyjąć sakrament namaszczenia chorych. Kościół zachęca, aby przyjmować ten sakrament zarówno przed trudną operacją jak i w sytuacji pogłębiającej się słabości osoby starszej (Por. KKK 1515).

Z badań prowadzonych przez CBOS w Polsce wynika, iż niestety coraz silniej zarysowuje się tendencja do rezygnacji ze świadomego przygotowania do śmierci. Coraz więcej Polaków, mimo iż deklaratywnie określają siebie katolikami, nie umie opowiedzieć się czy chce przygotowania do śmierci lub coraz mocniej wskazuje, iż lepsza jest śmierć bez jej pełnej świadomości. Osłabienie chrześcijańskiego i mocno zakorzenionego w polskiej tradycji zwyczaju przygotowania się do śmierci poprzez pojednanie z najbliższymi, załatwienie ważnych kwestii materialnych, przyjęcie sakramentu pokuty i pojednania, Eucharystii, namaszczenia chorych powoduje, iż ludzie cierpiący, umierający, zamiast zbliżać się do członków swojej rodziny, przyjaciół, sąsiadów, niejednokrotnie izolują się i ulegają lękom przed śmiercią. Powoli ujawniają się również zachowania dotyczące większej troski o estetyczny wygląd ciała umierającego a później zwłok niż o życie wieczne. Sakrament namaszczenia chorych daje człowiekowi umierającemu łaskę wzmocnienia odwagi, nadziei, by przezwyciężyć przeżywaną trwogę. Stąd niezwykle ważna rola kapelana, który obecny wśród ludzi cierpiących i umierających winien posiadać ogromne wyczulenie i wrażliwość na ich sytuację, dyspozycyjność oraz empatię, a jednocześnie zachować otwartość na służbę umierającym i ich rodzinom. Bardzo znaczące jest psychologiczne przygotowanie kapłana, aby nie tylko modlił się za powierzonych mu chorych i umierających, ale posiadał umiejętność komunikacji interpersonalnej, by z jednej strony nie obawiać się rozmawiać $\mathrm{z}$ cierpiącym i jego rodziną a $\mathrm{z}$ drugiej nie popełnić błędów zniechęcających chorych do kontaktu z kapłanem. Niekiedy bowiem zbytnia formalność kapłana buduje bariery, które trudno przekroczyć chorym i ich rodzinom. Bardzo znaczące jest przygotowanie kapłana do posługi kapelana w szpitalu do współtowarzyszenia 
chorym w ostatnim przejściu, przy jednoczesnym nie przejmowaniu ich problemów i trudności ${ }^{27}$.

Koniec ludzkiego życia i umieranie jest szczególnie czułym momentem w życiu człowieka ${ }^{28}$, stąd wydaje się, iż obecnie w dobie ponowoczesności szczególnie niezbędne jest przypominanie wierzącym czym jest sakrament namaszczenia chorych i jakie niesie ze sobą skutki. Katechizm Kościoła Katolickiego podaje następujące skutki sakramentu namaszczenia chorych: 1. Zjednoczenie chorego z męką Jezusa Chrystusa dla jego własnego dobra a także dla dobra Kościoła. 2. Wzmocnienie, udzielenie pokoju, wiary i odwagi, by na sposób chrześcijański przyjmować ból, cierpienie, starość, chorobę i śmierć. 3. Przebaczenie grzechów jeżeli człowiek chory lub umierający nie mógł ich otrzymać przez sakrament pokuty i pojednania. 4. Zdrowie jeśli służy to dobru duchowemu osoby. 5. Przygotowanie do przejścia do życia wiecznego (Por. KKK 1532).

W pastoralnej trosce o człowieka umierającego potrzebne jest mądre połączenie teologicznego i psychologicznego wymiaru tak, by kapłan nie pozostał wyłącznie na poziomie formalnego głoszenia prawd katechizmowych, zaś z drugiej strony, by nie pełnił tylko funkcji psychologa ${ }^{29}$. W rzeczywistości chrześcijańskiej śmierć nie jest kresem, ale w perspektywie tajemnic paschalnych męki, śmierci i zmartwychwstania Jezusa Chrystusa jest przejściem z rzeczywistości ziemskiej

${ }^{27}$ Por. P. Krakowiak, Rola duszpasterza w opiece paliatywno-hospicyjnej, w: Podręcznik wolontariusza hospicyjnego, red. P. Krakowiak, A. Modlińska, Gdańsk 2008; E. Dutkiewicz, Opieka duchowa nad umierajacym, w: Przed przejściem. Rozważania o opiece hospicyjnej, red. M. D. Śpiewakowska, R. Szpakowski, Warszawa 1997; Formy opieki, wychowania $i$ wsparcia w zreformowanym systemie pomocy społecznej, red. J. Brągiel, S. Badory, Opole 2005; N. Pikuła, Etos starości w aspekcie społecznym. Gerontologia dla pracowników socjalnych, Kraków 2011; N. Pikuła, Senior w przestrzeni społecznej, Warszawa 2013; Polska starość, red. B. Synak, Gdańsk 2002; Poznać, zrozumieć i zaakceptować starość, red. A. A. Zycha, Łask 2012; Prawda umierania i tajemnica śmierci, red. M. Górecki, Warszawa 2010; Śmierć $i$ wiara w życie pośmiertne w świetle nauk przyrodniczych i humanistycznych, red. M. Machnik, Olsztyn 2003; E. Trafiałek, Polska starość w dobie przemian, Katowice 2003; Z. Waleszczuk, W trosce o człowieka umierającego. Geneza hospicjum w Polsce, Wrocław 2004; Wybrane problemy osób starszych, red. A. Nowicka, Kraków 2006.

${ }^{28}$ Por. A. Błachnio, Pytanie o jakość życia w kontekście rozważań nad naturą starości, w: Starość i osobowość, red. K. Obuchowski, Bydgoszcz 2002, s. 13-52; Geriatria z elementami gerontologii ogólnej, red. T. Grodzicki, J. Kocemba, A. Skalska, Via Medica, Gdańsk 2006; J. Halicki, Edukacja seniorów w aspekcie teorii kompetencyjnej. Studium historyczno-porównawcze, Białystok 200o; A. Leszczyńska-Rejchert, Człowiek starszy i jego wspomaganie - w stronę pedagogiki starości, Olsztyn 2010; Pedagogika jesieni. Problemy wychowawcze ludzi starych, red. J. Homplewicz, Rzeszów 2003; Starość może być atrakcyjna, red. N. Pikuła, Kraków 2012; Starzenie się a satysfakcja z życia, red. S. Steuden, M. Marczuk, Lublin 2006.

${ }^{29}$ Por. E. Osewska, Wartość życia i cierpienia osoby starszej w perspektywie pedagogiczno-teologicznej, w: Człowiek wobec bólu, cierpienia i śmierci, red. J. Stala, N. Bravena, Kraków 2013, s. 11-22; Starość i osobowość, red. K. Obuchowski, Bydgoszcz 2002; M. Straś-Romanowska, Późna dorosłość. Wiek starzenia się, w: Psychologia rozwoju człowieka, tom 2, red. B. Harwas-Napierała, J. Trempała, Warszawa 2001, s. 263-292; Z. Szarota, Gerontologia społeczna i oświatowa. Zarys problematyki, Kraków 2004; B. Szatur-Jaworska, P. Błędowski, M. Dzięgielewska, Podstawy gerontologii społecznej, Warszawa 2006. 
do życia wiecznego. Bolesnym i trudnym, ale przejściem, bowiem Jezus Chrystus, który umarł i zmartwychwstał, jako pierwszy przeszedł ze śmierci do życia i zapoczątkował wszystkim wierzącym drogę przejścia z tego świata do Ojca.

\section{Proponowana literatura}

Błachnio A., Pytanie o jakość życia w kontekście rozważań nad natura starości, w: Starość i osobowość, red. K. Obuchowski, Bydgoszcz 2002, s. 13-52.

Centrum Badania Opinii Społecznej, Nasze postawy wobec umierania i śmierci. Komunikat $z$ badań, Warszawa 1994 (BS/183/162/94), s. 1-17, http://www.cbos.pl/SPISKOM. POL/1994/K_162_94.PDF (21.08.2014).

Centrum Badania Opinii Społecznej, O umieraniu i śmierci. Komunikat $z$ badań, Warszawa 2001 (BS/146/2001), s. 1-17, http://www.cbos.pl/SPISKOM.POL/2001/K_146_01. PDF (21.08.2014).

Centrum Badania Opinii Społecznej, Stosunek Polaków do śmierci. Komunikat $z$ badań, Warszawa 2005 (BS/98/2005), s. 1-12, http://www.cbos.pl/SPISKOM. POL/2005/K_098_05.PDF (21.08.2014).

Centrum Badania Opinii Społecznej, $W$ obliczu śmierci. Komunikat z badań, Warszawa 2012 (BS/165/2012), s. 1-5, http://www.cbos.pl/SPISKOM.POL/2012/K_165_12.PDF (21.08.2014).

Człowiek wobec bólu, cierpienia i śmierci, red. J. Stala, N. Bravená, Kraków 2013.

Dąbrowski K., Zdrowie psychiczne i problem śmierci, „Zdrowie psychiczne” (1980) nr 4, s. 7-17.

Dutkiewicz E., Opieka duchowa nad umierajacym, w: Przed przejściem. Rozważania o opiece hospicyjnej, red. M. D. Śpiewakowska, R. Szpakowski, Warszawa 1997.

Feifel H., Branscomb A., Who's afraid of death, „Journal of Abnormal Psychology” 8 (1973) nr 3, s. 282-288.

Feifel H., Psychologia a śmierć, „Nowiny Psychologiczne” (1990) nr 5-6, s. 3-16.

Formy opieki, wychowania i wsparcia w zreformowanym systemie pomocy społecznej, red. J. Brągiel, S. Badory, Wyd. Uniwersytetu Opolskiego, Opole 2005.

Geriatria z elementami gerontologii ogólnej, red. T. Grodzicki, J. Kocemba, A. Skalska, Via Medica, Gdańsk 2006.

Halicki J., Edukacja seniorów w aspekcie teorii kompetencyjnej. Studium historyczno-porównawcze, Białystok 2000.

Kępiński A., Lęk, Warszawa 1977.

Kępiński A., Rytm życia, Kraków 1978.

Kępiński A., Schizofrenia, Kraków 1992. 
Krakowiak P., Rola duszpasterza w opiece paliatywno-hospicyjnej, w: Podręcznik wolontariusza hospicyjnego, red. P. Krakowiak, A. Modlińska, Gdańsk 2008.

Leszczyńska-Rejchert A., Człowiek starszy i jego wspomaganie - w strone pedagogiki starości, Olsztyn 2010.

Osewska E., Wartość życia i cierpienia osoby starszej w perspektywie pedagogiczno-teologicznej, w: Człowiek wobec bólu, cierpienia i śmierci, red. J. Stala, N. Bravena, Kraków 2013, s. 11-22.

Pedagogika jesieni. Problemy wychowawcze ludzi starych, red. J. Homplewicz, Rzeszów 2003.

Pikuła N., Etos starości w aspekcie społecznym. Gerontologia dla pracowników socjalnych, Kraków 2011.

Pikuła N., Senior w przestrzeni społecznej, Warszawa 2013.

Piotrowski J., Żemojtel-Piotrowska M., Skala lęku i fascynacją śmiercią, „Polskie Forum Psychologiczne" 14 (2009) nr 1, s. 90-109.

Polska starość, red. B. Synak, Gdańsk 2002.

Poznać, zrozumieć i zaakceptować starość, red. A. A. Zycha, Łask 2012.

Prawda umierania i tajemnica śmierci, red. M. Górecki, Warszawa 2010.

Starość i osobowość, red. K. Obuchowski, Bydgoszcz 2002.

Starość może być atrakcyjna, red. N. Pikuła, Kraków 2012.

Starzenie się a satysfakcja $z \dot{z} y c i a$, red. S. Steuden, M. Marczuk, Lublin 2006.

Straś-Romanowska M., Późna dorosłość. Wiek starzenia się, w: Psychologia rozwoju człowieka, tom 2, red. B. Harwas-Napierała, J. Trempała, Warszawa 2001, s. 263-292.

Szarota Z., Gerontologia społeczna i oświatowa. Zarys problematyki, Kraków 2004.

Szatur-Jaworska B., Błędowski P., Dzięgielewska M., Podstawy gerontologii społecznej, Warszawa 2006.

Śmierć $i$ wiara $w$ życie pośmiertne w świetle nauk przyrodniczych i humanistycznych, red. M. Machnik, Olsztyn 2003.

Trafiałek E., Polska starość w dobie przemian, Katowice 2003.

Waleszczuk Z., W trosce o człowieka umierającego. Geneza hospicjum w Polsce, Wrocław 2004.

Wybrane problemy osób starszych, red. A. Nowicka, Kraków 2006.

Życie i śmierć. Wyzwania działalności charytatywnej, red. J. Stala, Tarnów 2012. 